\title{
Research Regarding the Production of Planting Material for the Decorative Species Paulownia Tomentosa Thumb
}

\author{
Rodica SOARE ${ }^{1 *}$, Ovidiu PĂNIȚĂ ${ }^{1)}$, Elena BONCIU ${ }^{1)}$, Marin SOARE ${ }^{1)}$ \\ ${ }^{1)}$ University of Craiova, Faculty of Agriculture and Horticulture, Libertatii Street, no 19, 200583, Dolj, Ro- \\ mania \\ ${ }^{*}$ Corresponding author, e-mail: soarerodi@yahoo.com
}

Bulletin UASVM Horticulture 71(2) / 2014

Print ISSN 1843-5254, Electronic ISSN 1843-5394

DOI:10.15835/buasvmcn-hort:10602

\begin{abstract}
Development of organic farming has led to the production of new organic fertilizers. They can increase seedlings vigour and resistance to pathogens and pests attack as well as a good survival in less favourable conditions after crop establishment. In this paper, a preliminary study was conducted to evaluate the response of Paulownia seedlings to organic fertilizers. Currently, the interest for this species is increasing due to its many qualities: decorative rapid growth, the honey tree and an excellent wood for timber, especially plant biomass production and capacity of air purification in polluted areas. After transplanting, 3 treatments have been applied to seedlings root, at an interval of 7 days. Response assessment was done through biometric measurements on height and stem diameter, number of leaves/plant, root length and leaf area. Treated seedlings were found to be superior to the untreated seedlings. Among the treatments applied, Organic NK-Fertilizer gave a significant advantage over the rest of the treatments in terms of seedlings vigor while bacterial culture led to a good development of the root system.
\end{abstract}

Keywords: height, leaf area, root length, stem diameter

\section{INTRODUCTION}

Paulownia tomentosa (Thunb.) Steud belongs to the monogeneric family Paulowniaceae, and sometimes is included in the Scrophulariaceae family. It is a species originally from China; in Romania is cultivated in parks and gardens with ornamental character due to its campanulated and pleasant smelling flowers, (Netoiu et al., 2008). Lately an increasing emphasis is put on expanding the culture of this species due to its many qualities: decorative, rapid growth, honey tree and excellent wood for timber, musical instruments, and especially for plant biomass yield.

Leaves present a high nitrogen content and can be used as green manure or as fodder for animals (Zhu et al., 1986; Rahman et al., 2013). Also, this specie can be planted in order to reduce pollution degree, as it has pubescent, large leaves and thus a large capacity air purification (Simion,
2009). Also, it can be used for the mining areas recovery (Rahman et al., 2013).

Continue fertilization with chemical fertilizers has adverse effects on the environment, so the production of new organic fertilizers is a necessity. Their use in practice requires extensive tests on different species. Scientific researches on such fertilizers (worm compost, bacterial culture and other bioactive products) were made on various species: Gypsophila-Atanasova and Zapryanova (2013); corn-Petkova (2007); pepper-Kentelki (2010); apple -Radomirska and Sotirov (2012); ryegrass-Schenck zu Schweinsberg-Mickan and Müller (2009); aromatic plants - Milica (2013); etc., but not on Paulownia.

Paulownia seedlings are sensitive to freeze in the first years of vegetation (Simion, 2009). Bioactive products have favorable effects on plant growth and development, improve the resistance to unfavorable factors, stimulate seed germination 
and accelerate vegetative growth (Dinu et al., 2010; Hoza, 2010).

Organic materials from municipal and industrial waste and residues from agriculture forestry are strongly recommended for use as renewable resources to mitigate their negative impact on regional and global environmental degradation in favour of the environment sustainability (Dede et al., 2006).

\section{MATERIAL AND METHODS}

The biological material was obtained by producing seedlings, with seeds from the Paulownia tomentosa species, in 2013, in the laboratory of Plant Breeding, Faculty of Agriculture and Horticulture, Craiova, Romania. Seedlings were produced according to general production technology, respectively: sowing by spraying, on peat substrate and then picked into cellular trays filled with professional peat. Sowing was done in the second decade of April and the transplanting was done after 20 days. Care works were the general, aiming to achieve healthy and vigorous seedlings by ensuring the optimum temperature $\left(20-22^{\circ} \mathrm{C}\right)$. Against the proliferation of pests and diseases during the growth and development of seedlings, it were applied treatments at intervals of 14 days.

The literature presents numerous data on the use of bioactive substances with essential role in the crops growth. In this regard, several products were used to obtain vigorous seedlings to stimulate the biological potential of seedlings to minimize the pollution degree of the natural environment. In this study it were used as biostimulation products newly introduced on the market:

- Organic NK-Fertilizer, liquid using animal byproducts, contents: 9,4\% total nitrogen (116 $\mathrm{g} / \mathrm{l} \mathrm{N}), 1,1 \%$ potassium oxide $\left(14 \mathrm{~g} / \mathrm{l} \mathrm{K}_{2} 0\right)$;

- Organic Fertilizer with Bacterial culture on the basis of: Azospirillum lipoferum, Azotobacter vinelandii, Bacillus megaterium, Bacillus circulans, Bacillus subtilis, Pseudomonas fluorescens, Micrococcus roseus;

- Liquid stimulant and derived from California red worm (worm compost). It is rich in humic and fulvic acids, and macro and micro elements in hepatic shape (which can be easily absorbed by plants), salts and minerals.

The experimental design consisted of four versions: V1-seedlings untreated; V2-seedlings treated with Organic NK-Fertilizer 1\%; V3seedlings treated with bacterial culture $0.5 \%$; V4seedlings treated with liquid worm compost $1 \%$.

After transplant, 3 treatments were applied to the seedlings root, at an interval of 7 days.

To highlight the effect of the treatments on the morphological characteristics of Paulownia seedlings, observations and biometric measurements were made regarding the height and diameter of the stem, the number of leaves/ plant, root length and leaf area. To determine the leaf surface a planimeter was used.

The obtained results were statistically analyzed calculating the arithmetic mean, standard deviation of arithmetic mean and the coefficient of variance. Emphasizing the morphological differences between the variants studied was done by using the significance of differences (LSD) analyze. Te link between morphological characters was determined with the help of correlation coefficients (r) (Ciulca, 2002).

\section{RESULTS AND DISCUSSION}

During the growth and development of seedlings, were carried out tests and statistical calculation which highlighted the effect of rooting products. The average data obtained on biometric measurements are presented in Tab. 1, 2, 3, 4 and 5. Results attested the effect of treatments with bioactive products on morphological parameters from Paulownia seedlings. The stem height was between $5.31 \mathrm{~cm}$ (V2)-10.70 $\mathrm{cm}$ (V3) and the coefficient of variation was between 10.14 and $19.89 \%$, indicating individuals with middle variability. Significant differences from control were observed in variants V3 and V4 (Tab. 1).

Atanasova and Zapryanova (2013), when applying an organic fertilizer produced in the same range as worm compost, have found that $1.5 \%$ concentration stimulated the growth of Gypsophila plants (height).

Stem diameter at package ranged from 2.6 $\mathrm{mm}$ (V1) up to $3.02 \mathrm{~mm}$ (V2). The thickening of the seedlings stem, the morphological trait that confers resistance to plants on falling, record low variability in $\mathrm{V} 2$ and $\mathrm{V} 4$ and middle variability in V1 and V3. In variant V2, there were significant differences compared to control, and in V4, significant differences were measured (Tab. 2). Similar significant results for stem diameter were obtained by Atanasova and Zapryanova (2013) by 
Tab. 1. Variability in plant height character of Paulownia seedlings under the influence of bioactive substances

\begin{tabular}{ccccc}
\hline \multirow{2}{*}{ Variant } & \multicolumn{4}{c}{ Plant Heigh (cm) } \\
\cline { 2 - 5 } & ${\mathrm{X} \pm \mathrm{s}_{\mathrm{v}}}$ & $\mathrm{s} \%$ & $\pm \mathrm{d}$ & Signification \\
\hline V1-Mt & $8.22 \pm 1.14$ & 13.92 & - & - \\
\hline $\mathrm{V} 2$ & $5.31 \pm 0.52$ & 14.06 & -2.91 & 00 \\
\hline V3 & $10.70 \pm 1.08$ & 10.14 & +2.48 & $*$ \\
\hline V4 & $10.07 \pm 2.00$ & 19.89 & +1.85 & $*$ \\
\hline
\end{tabular}

LSD 5 \%=1.77; LSD $1 \%=2.71$; LSD $0.1 \%=4.35$

Tab. 2. Variability of diameter character on package at the Paulownia seedlings under the influence of bioactive substances

\begin{tabular}{ccccc}
\hline \multirow{2}{*}{ Variant } & \multicolumn{4}{c}{ Stem Diameter $(\mathrm{mm})$} \\
\cline { 2 - 5 } & $\mathrm{X} \pm \mathrm{s}_{\mathrm{v}}$ & $\mathrm{s} \%$ & $\pm \mathrm{d}$ & Signification \\
\hline $\mathrm{V} 1$ & $2,6 \pm 0,51$ & 19,86 & - & - \\
\hline $\mathrm{V} 2$ & $3,02 \pm 0,06$ & 8,09 & $+0,42$ & $*$ \\
\hline V3 & $2,7 \pm 0,51$ & 17,80 & $+0,1$ & - \\
\hline V4 & $2,83 \pm 0,16$ & 5,58 & $+0,23$ & $*$ \\
\hline
\end{tabular}

LSD 5\%=0.21; LSD 1\%=0.34; LSD 0.1\%=0.54

Tab. 3. Variability in the number of leaves of Paulownia seedlings under the influence of bioactive substances

\begin{tabular}{ccccc}
\hline \multirow{2}{*}{ Variant } & \multicolumn{4}{c}{ No. of leafs } \\
\cline { 2 - 5 } & ${\mathrm{X} \pm \mathrm{s}_{\mathrm{y}}}_{\mathrm{y}}$ & $\mathrm{s} \%$ & $\pm \mathrm{d}$ & Signification \\
\hline $\mathrm{V} 1$ & $5.4 \pm 0.63$ & 10.9 & - & - \\
\hline $\mathrm{V} 2$ & $6.7 \pm 1$ & 14.28 & +1.3 & - \\
\hline $\mathrm{V} 3$ & $5.8 \pm 1.13$ & 19.57 & -0.4 & - \\
\hline $\mathrm{V} 4$ & $6.0 \pm 2.94$ & 15.71 & +0.6 & \\
\hline
\end{tabular}

LSD 5\%=1.48 ; LSD 1\%=2.27; LSD 0.1\%=3.64

Tab. 4. Variability of leaf area in seedlings of Paulownia under the influence of bioactive substances

\begin{tabular}{ccccc}
\hline \multirow{2}{*}{ Variant } & \multicolumn{4}{c}{ Leaf Area $\left(\mathrm{cm}^{2}\right)$} \\
\cline { 2 - 5 } & ${\mathrm{X} \pm \mathrm{s}_{\mathrm{v}}}_{\mathrm{n} 1}$ & $\mathrm{~s} \%$ & $\pm \mathrm{d}$ & Signification \\
\hline $\mathrm{V} 1$ & $6.65 \pm 1.25$ & 18.87 & - & - \\
\hline $\mathrm{V} 2$ & $4.54 \pm 1.35$ & 29.89 & -2.11 & - \\
\hline $\mathrm{V} 4$ & $8.32 \pm 2.40$ & 25.82 & +1.67 & - \\
\hline
\end{tabular}

LSD 5\%=2.7; LSD 1\%=4.12; LSD 0.1\%= 6.62

Tab. 5. Variability of root length in seedlings of Paulownia under the influence of bioactive substances

\begin{tabular}{ccccc}
\hline \multirow{2}{*}{ Variant } & \multicolumn{5}{c}{ Root lenght $(\mathrm{cm})$} \\
\cline { 2 - 5 } & $\mathrm{X}_{ \pm} \mathrm{s}_{\mathrm{v}}$ & $\mathrm{s} \%$ & $\pm \mathrm{d}$ & Signification \\
\hline $\mathrm{V} 1$ & $5.48 \pm 0.93$ & 17.13 & - & - \\
\hline $\mathrm{V} 2$ & $5.05 \pm 0.61$ & 12.21 & -0.43 & - \\
\hline $\mathrm{V} 3$ & $6.72 \pm 2.20$ & 29.84 & 1.24 & $* * *$ \\
\hline $\mathrm{V} 4$ & $4.61 \pm 0.58$ & 12.58 & -0.87 & 00 \\
\hline
\end{tabular}

LSD5 $\%=0.48 ;$ LSD1 $\%=0.75 ;$ LSD $0.1 \%=1.20$ 
applying organic worm cast application on flower species, in concentrations of $1 \%$ and $1.5 \%$.

At planting, Paulownia seedlings presented between 5.4 (V1) and 6.7 (V2) leaves/plant. Coefficient of variation for number of leaves shows medium variability, ranging between 10.9 and $19.5 \%$. There were no significant differences compared to the controls (Tab. 3). Hashish (2011), showed an increase of Paulownia leaves by applying Fe 100 ppm.

In terms of leaf area, this one registered a amplitude of variation between $4.54 \mathrm{~cm}^{2}$ (V2) and $8.32 \mathrm{~cm}^{2}$ (V3). In V1, individuals presented mid variability of $18.87 \%$, while in the other variants individuals had a high variability, from $22.48 \%$ to $29.89 \%$. Nor in the case of this character were found significant differences compared to the control (Tab. 4). After Hashish (2011), the best results in regard to leaf area were obtained from the treatment with an liquid biofertilizer (containing $\mathrm{N}$-fixing and P-dissolving bacteria)) +75 NPK.

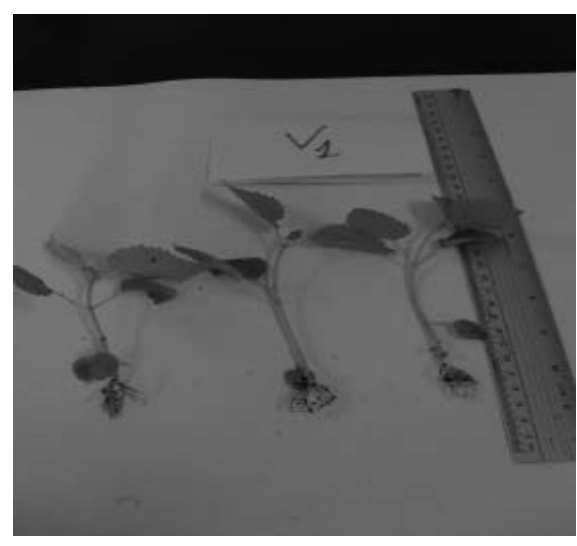

a.
Regarding the growth of roots under the influence of organic treatments values between $4.61 \mathrm{~cm}(\mathrm{~V} 4)$ and $6.72 \mathrm{~cm}$ (V3) were recorded. Variability of individuals was greater in V3, respectively $29.84 \%$ and middle in the other variants, namely $12.21 \%$ (V2), $12.58 \%$ (V4) and $17.13 \%$ (V1). In variant 3 there was a very significant positive difference compared to the control (Tab. 5, Photo 1 a.b.) and variant 4 has registered significant negative difference. Similar results were obtained by Ćirković-Mitrović et al. (2012) in walnut seedlings treated with bacterial culture where this product has led to stimulating root length.

Analyzing the values of correlation coefficients we can observe the existence of very significant positive correlations between plant height and leaf area $\left(+0.998^{* * *}\right)$, and between the package diameter and number of leaves $\left(+0,989^{* * *}\right)$. In the case of the rest of the studied characters not significant correlations were recorded (Tab. 6).

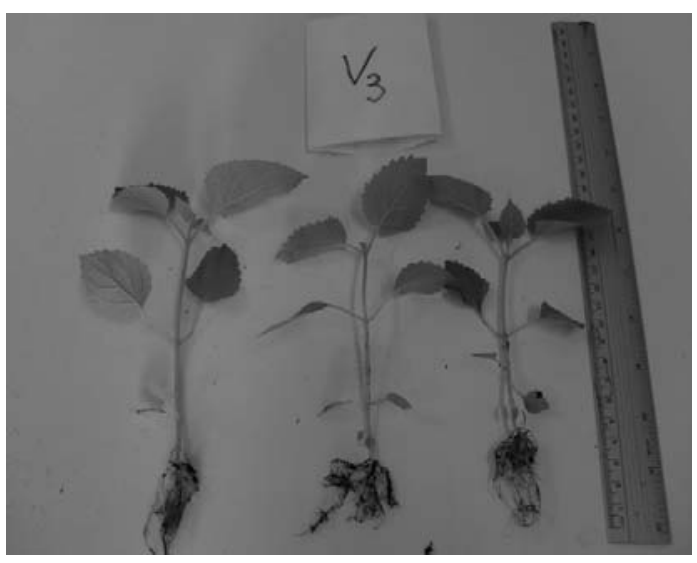

b.

Photo. 1. Root length in Paulownia seedlings in variant 3(b) compared with V1 (a)

Tab. 6. Correlations between morphological characters studied.

\begin{tabular}{ccccc}
\hline Character & Stem Diameter & Leaf No. & Leaf Area & Root Lenght \\
\hline $\begin{array}{c}\text { Plant } \\
\text { Height }\end{array}$ & -0.619 & -0.633 & $0.998^{* * *}$ & 0.415 \\
\hline $\begin{array}{c}\text { Stem } \\
\text { Diameter }\end{array}$ & - & $0.989^{* * *}$ & -0.657 & -0.496 \\
\hline $\begin{array}{c}\text { Leaf } \\
\text { No. }\end{array}$ & - & - & -0.664 & -0.371 \\
\hline $\begin{array}{c}\text { Leaf } \\
\text { Area }\end{array}$ & - & - & - & 0.460 \\
\hline
\end{tabular}

* Significant for p 5\%; ** Significant for p $1 \%,{ }^{* * *}$ Significant for $\mathrm{p} 0.1 \%$ 


\section{CONCLUSIONS}

Obtained results regarding the improvement of production technology on Paulownia seedlings by treatment with organic products allows the following conclusions:

- The variant 1 - untreated control, seedlings were elongated, very tender and presented light green color;

- In variant 2, treated with Organic NK-Fertilizer, vigorous seedlings were obtained, unstretched, having dark green color, corresponding to planting;

- In variant 3 , treated with bacterial culture, the seedlings have presented a better development of the root system;

- In variant 4 treatments determine an increase of seedlings height and stem diameter;

- Best variants reccommended to be used in the obtaining of Paulownia seedlings are V2 ande V3;

- Seedlings were planted in the nursery and the behavior will be followed in the coming years, according to climatic conditions from the southwest of Romania.

Acknowledgements. This work was partially supported by the grant number $13 \mathrm{C} / 27.01 / 2014$ awarded in the internal grant competition of the University of Craiova".

\section{REFERENCES}

1. Atanasova B, Zapryanova N (2013). Effect of biological fertilizer Lumbrikol on growth and development of Gypsophila. Determination of the optimal amount of fertilizer in soil dieting of plants. Subtropical and Ornamental Horticulture 49:300-306.

2. Ćirković-Mitrović $\mathrm{T}$, Brašanac-Bosanac $\mathrm{L}$, Popović $\mathrm{V}$ (2012). Effect of fertiliser application on morphological characteristics of walnut (Juglans regia L.) seedlings http:// semenarska.rs/UNS-PSU/radovi/1/13\%20CIRKOVIC $\% 20$ 149-164.pdf

3. Ciulca S (2002). Tehnică experimentală. Ed. Mirton Timişoara, pp 219.
4. Dede OH, Köseglu G, Özdemir S, Çelebi A (2006). Effects of organic waste substrates on the growth of Impatiens, Turk J Agric For 30: 375-381.

5. Dinu M, Dumitru MG, Cimpoiaşu VM (2010). The use of organic products at culture of carrot in succession. Journal of Horticulture, Forestry and Biotechnology, 1:172-176.

6. Hashish KhII (2011). Effect of chemical and biofertilizers on growth of Paulownia seedlings. http://agris. Fao. org /agrissearch D=EG20120 00942. Accesed 12.05.2014.

7. Hoza Ghe (2010). Research regarding the effect of foliar fertilization on tomato growth and fructification. Journal of Horticulture, Forestry and Biotechnology, 1:257-260.

8. Kentelki EC (2010). Research on early production and total production in varieties of sweet peppers ( $\mathrm{Ho}_{\mathrm{F}}$ Julianus, Campona $F_{1}$ ) by fertilization and irrigation method in greenhouses. Scientifical pappers, serie B Horticulture 54:131-136.

9. Milica A (2013). The influence of fertilization on yield of caraway, anise and coriander in organic agriculture. Journal of Agricultural Sciences 58 (2):85-94.

10. Netoiu C, Visoiu D, Bădele O (2008). Dendrologie. Editura Eurobit Timisoara, pp 235.

11. Petkova G (2007). Effect of the vermicompost on the microbiological activity of leached smolnitsa in the rhizosphere of corn / G. Petkova, K. Nedyalkova, Z. Petkova, I. Valchovski//Sci. Rep. of Int. Conference "60th Anniversary of the N. Pushkarov Institute of Soil Science": Soil Science the Foundation of Sustainable Agriculture and Environmental Protection, pp. 193-195.

12. Radomirska I, Sotirov D (2012). Influence of the foliar fertilization on quality characteristics and economic efficiency of apple cultivar Smoothi. DC:634.11-152.61(497.2).

13. Rahman Md A, Rahman F, Rahmatullah M (2013). In vitro regeneration of Paulownia tomentosa Steud. Plants through the induction of adventitious shoots in explants derived from selected mature trees, by studying the effect of different plant growth regulators. American-Eurasian Journal of Sustainable Agriculture, 7(4): 259-268.

14. Schenck zu Schweinsberg-Mickan M, Müller T (2009). Impact of effective microorganisms and other biofertilizers on soil microbial characteristics, organic-matter decomposition, and plant growth. J. Plant Nutr. Soil Sci. 172: 704-712.

15. Simion FO (2009). Research on the production of seedlings and introduction in the Parks of the Paulownia tomentosa (Thunb.) sieb. specie. phD Thesis: http://cis01.central. ucv. ro/upload/lucrari_dr/260_rez-ro.pdf.

16. Zhu ZH, Chao CJ, Lu XY, Xiong YG (1986). Paulownia in China: Cultivation and Utilization, Asian Network for Biological Sciences and International Development Research Centre, Singapore, pp. 1-65. 